\title{
Becoming American: The Hmong American Experience
}

\section{Kou Yang \\ California State University, Stanislaus}

Hmong Americans, who came from a pre-literate society and rural background, went through many acculturation barriers and have had many successes between the time they first arrived in 1975 and the year 2000. Their first decade was preoccupied with their struggle to overcome cultural shock and acculturation difficulties. The second decade is their turning point to be new Americans, beginning to run for political office, establish business enterprises, achieve in education, and reduce their high rate of unemployment and welfare participation. Hmong Americans in 2000 appeared to have achieved much,yet have some serious challenges still ahead.

This paper details Hmong experience in America. It discusses their twenty-five challenging years of becoming Americans, and emphasizes Hmong Americans perspectives of their own American experience, including issues related to social, cultural, educational, economic, and political development. 


\section{Introduction}

The year 2000 marks the twenty-fifth anniversary of Hmong history in America, and it is also twenty-five years after the end of the U.S. Secret War in Laos, which resulted in many Hmong of Laos coming to America. The year 2000 is also the end of the 20th century-an unprecedented century of changes and development for the Hmong. It probably brought more changes to the Hmong than any other century in their long history. The year 2000 is an opportune moment to take a look at the experience of the Hmong in America. Unlike European immigrants, post 1965 Asian immigrants, and other refugee groups from Indochina, the Hmong were culturally, educationally, and technologically unprepared to acculturate with America, the most developed country in the world. This conjuncture of the Hmong and American cultures has produced some significant strains in Hmong traditions. Nonetheless, Hmong have also produced some unusual success stories. ${ }^{1}$. This paper is an attempt to explore the current experience of Hmong Americans, identify some of their successes as well as their current difficulties, and place the status of Hmong Americans into proper perspective. It emphasizes Hmong Americans' perspective of their history and other experience in America, including discrimination and issues related to social, cultural, and economic development.2

The term Hmong Americans in this paper refers to all descendants of Hmong ancestrywho are now residents or citizens of the United States. The term Hmong 3 refers to an ancient Asian ethnic group who call themselves "Hmong" but who are labeled by outsiders as "Miao" in China, and "Meo" in Thailand.

\section{Background of the Hmong Americans}

The Hmong are an ancient Asian ethnic group found in China, Vietnam, Laos, Thailand, Myanmar (Burma), and after 1975, in America, Australia, and Europe. 4 They call themselves "Hmong" not Miao or Meo, the name given to them by nonHmong, and they prefer to be called by the name "Hmong".5. They are believed to have lived along the Yellow River area of China around 3000 B.C. 6 If this account is accurate, then the 
Hmong have a known history of at least 5000 years in China. Many scholars have gone further by suggesting that the Hmong were the aborigines of central China, ${ }^{7}$ and that the Hmong were the first settlers of the basin of the Yellow River. ${ }^{8}$ Another school of thought suggests that "of their pre-history only one thing is certain, that is the Miao [Hmong] were in China, before the [Han] Chinese, for it is the latter who indicate the presence of the Miao in the land". ${ }^{9}$

During their long history, the Hmong went through many developments and struggles and through many periods of war and peace. ${ }^{10}$ They have been pushed and pulled from north to south, from east to west, and from the fertile lowlands of China to the desolate mountainous highlands. ${ }^{11}$ The inhospitable eco-geographical mountain environment might be one of the many main factors that trapped the Hmong into poverty and their many distinctive technological and socio-political conditions. 12

The Hmong in Southeast Asia came from China. They began their southward migration to Southeast Asia during the 19th century when troubles plagued China. The decline of the Qing dynasty, the Opium War, the Taiping Rebellion, and foreign aggression occurred during this century. ${ }^{13}$ The results-war indemnity, heavy taxation, poverty, and other conditions-were the push-factors for many southern Chinese to migrate to Hawaii and to San Francisco in the mid-19th century. ${ }^{14}$ The Hmong might have been pushed out by these same factors along with the possibility that the Qing and other ruling majorities oppressed the Hmong. ${ }^{15}$

A few Hmong in Southern China left during these periods to Southeast Asia, and some were found in Laos around 1810.16 Gradually they migrated to Vietnam and Laos, and later to Thailand and Myanmar (Burma). Since their arrival in Laos around 1810 the Hmong have lived a mostly peaceful life in the highlands, except for three wars in which they became involved. 17 The first two wars were waged against the French colonial government in Laos to protest heavy and unjust taxation. The first took place in 1896.18 The second war was known as the "War of the Insane," and it occurred between 1919 and 1921.19 The last war-the most well known war in modern Hmong history-was the United States Central 
Intelligence Agency's Secret War in Laos, and it lasted from the early 1960 s to 1975.20 It is called the Secret War because the CIA did not tell the U.S. Congress and the American public about their involvement in Laos due to specific treaty stipulations preventing the US from having ground troops in Laos.

Although this last war caused heavy casualties and tremendous upheaval for the Hmong of Laos,21 it also pushed and pulled many Hmong into education, modernization, and most importantly, socio-political recognition, ${ }^{22}$ It was in the first doctoral dissertation among the Hmong by Yang Dao in 1972 that the true name of Hmong not Miao or Meo, the names imposed on them by outsiders, was brought to light, and that Hmong want to be called by the name they call themselves, Hmong. ${ }^{23}$

In less than 200 years the Hmong of Laos have undergone a total change in their identity and status from voluntary immigrant non-citizens to full and active participants in Laotian social, economic, and political affairs. The Hmong were not accepted as full citizens of Laos until 1947.24 By the beginning of 1975 the Hmong of Laos had one minister, one chief procurator of the Laotian Supreme Court, one general, three deputies to the Lao National Assembly, two members of the National Political Consultative Council, one person with a Ph.D., and more than thirty students studying in universities abroad. ${ }^{25}$

The end of the U. S. Secret War in Laos in 1975 gradually caused more than ten percent of the population of Laos to become refugees abroad.26 More than a third of these refugees are Hmong. Approximately one half of the 300,000 Hmong of Laos have fled the country since 1975. During the U.S. Secret War, the Hmong of Laos were divided into three factions: the right, neutral and left.27 It is estimated that onethird of them belonged to the right faction who allied themselves with the Royal Lao Government supported by the CIA. Another one-third of the Hmong of Laos were on the opposing side; they fought on the side of the communist Pathet Lao. The last group, who composed of mostly Hmong peasants, were neutral to the conflict yet suffered from it as much as the other two groups. There are in 2001 more than $200,000 \mathrm{Hmong}$ in Laos, and they continue to take active roles in the affairs of the 
country. Hmong continue to have a few high-ranking officials, including one minister, a Vice President of the Lao National Assembly, and one provincial governor.

The Hmong began to leave Laos in May 1975; by the year's end a few Hmong refugees had already resettled permanently in America. About 750 Hmong came to the United States in early 1976,28 and their numbers grew slowly but steadily. Hmong refugee resettlement in the United States peaked in 1980, when about 27,000 Hmong were admitted,29 Their population grew rapidly in the early 1980 to an estimated 100,000 in 1989.30 Although the United States continued to admit Hmong refugees up until the end of the 1990s, more than 10,000 Hmong refugees still areliving legally or illegally in Thailand. By the end of 1999 Hmong Americans were estimated to number $200,000.31$ This rapid growth is attributed to the Hmong's high fertility and low mortality rates and to the past continuous influx of Hmong refugees into this country. In the 1990 census Hmong Americans made up 1.3\% of all Asian Americans. ${ }^{32}$ Among all Asian groups in America the Hmong represent the youngest population, with a median age of about thirteen. They also have large families: 6.6 people per household.33 This might be explained by their past agricultural lifestyle and their traditional preferences for large families and for having more than two generations living under one roof. In addition use of effective fertility control technology, such as oral contraceptives, is often not readily available and/or encouraged within the Hmong community. The size of a large Hmong household in Laos varies from ten to more than twenty persons and can include children, parents, grandparents, cousins, aunts and uncles, and other members of the extended family. ${ }^{34}$

In the early days of resettlement the Hmong, like other refugees from Indochina, were dispersed throughout America. In the early 1980s many Hmong began to migrate to California in what is known as a secondary migration. By the end of 1986, approximately 46,000 (more than half the Hmong in the United States) were living in California. ${ }^{35}$ It was during this time that Fresno, California, became the capital of the $\mathrm{Hmong}$-the largest concentration of Hmong in America. The Hmong community in Fresno grew from one family in 1977 to five families in 1979 to 2,000 in 1980 and to about 35,000 in 
1993.36 The mid-1990s saw a reversal of this trend with Hmong moving out of California, especially Fresno.37 To escape high unemployment and poor economic conditions many Hmong moved out of Central California cities to Minnesota, Wisconsin, and other mid-western states. ${ }^{38}$ Fresno, which topped the list of cities with the largest concentration of Hmong in the 1980s and early 1990s, dropped to second place in 1999. The Twin Cities-St. Paul and Minneapolis, Minnesota-with more than 60,000 Hmong, now occupy the top spot. 39

In the 1980s and early 1990s the Hmong were among the poorest and most politically passive Asian Americans. The 1990 Census, for example, indicates that sixty-five percent of Hmong Americans were unemployed, and more than sixty percent lived below the poverty line. 40 The Hmong were basically in the stage of cultural shock. Gradually they have learned to cope and have adjusted to their new life in America. Many success stories of the Hmong begin after 1990. The election of Choua Lee, a Hmong woman, to the Board of Education for the St. Paul Public Schools in 1992 marked not only the beginning of Hmong's participation in the American political system but also their social and economic development. More Hmong individuals were elected to public offices in Minnesota, Wisconsin, and Nebraska. The rate of Hmong unemployment and welfare participation began to decline, as more Hmong participated in the American labor market. Hmong businesses expanded and grew. Hmong restaurants in Detroit, for example, multiplied from only a few in the early 1980 s to more than 100 by the end of 1999.41.More importantly the Hmong community began to cast away the label of refugee and to call themselves Hmong Americans. They began to exercise their rights and responsibilities as American citizens and at the same time to work to retain the best of their cultural heritage. The changes in the last decade show a remarkable level of social adaptation to mainstream America by Hmong Americans. From a pre-literate society, the Hmong in 2000 have more than 120 doctorates, nine tenured and tenure-track university professors, three city council persons, and others in significant positions. Additionally, Hmong Americans have developed their unique culture in America: they have Hmongrapcomedy, Hmonglish, and 
Hmong American music, dance, arts, and media. They have, indeed, come a long way but still have a long way to go to overcome many of their acculturation problems, such as family conflict, youth delinquency, poverty, health, and other issues.

\section{The Acculturation of Hmong Americans}

The meeting of Hmong and American cultures has created many success stories, and distinctive cultural barriers, economic hardship, family conflict, youth delinquency, and health and mental health issues. Unlike European immigrants, post1965 Asian immigrants, and other refugee groups from Indochina, Hmong were one of the Indochinese refugee groups least prepared to adjust to life in America.

The Hmong culture is shaped and formed by a long history of being an oppressed minority, with a group-oriented patriarchal clan system, a belief in animism and ancestral worship, an oral tradition, a rural lifestyle, and slash-and-burn agriculture.42 Their background resembles that of the early Chinese immigrants to San Francisco in the 19th century who were mostly peasants. These rural southern Chinese farmers were mostly uneducated and from poor peasant families. 43 When they arrived in California, the Chinese formed associations based on their clans, dialests, and/or districts in China.44 The Hmong, too, use their clan names as a base for many of their organizations in America. Organizations such as the Lo Society Educational Council, Thao Universal, Xing Educational Way, and Yang Family Association exist in almost all of the eighteen known Hmong American clans. Many Hmong in central California grow specific crops, such as strawberry, tomato, bean, bok choy, and lemon grass, and their farming is similar to the agricultural work of the earlier Chinese and Japanese Americans. Like the early Chinese in America, the Hmong came to America from a rural background and with no formal educational training.

The Hmong are very different from other post-1965 Asian immigrants whose members include not only many city dwellers but also professionals. The post-1965 Chinese immigrants "came from urban backgrounds, were educated in Hong Kong, mainland China, or Taiwan, and are Mandarin speaking, in contrast to the Cantonese (Guangdong) origin, Toysanese- 
speaking (Taishan hua) Chinese resident population", 45 which comprised most of the earlier immigrants. The Immigration Act of 1965 abolished the national origins system and gave a high priority to family reunification and to both skilled and unskilled workers. ${ }^{46}$ This Act has been the main factor in the rapid growth of the Asian American population, especially the educated and professionals. ${ }^{47}$

Adjusting to a new cultural environment is not new to the Hmong48, however the extremely large cultural gap between the Hmong and mainstream Americans have created formidible obstacles to the traditional coping skills and folkways of the Hmong. These cultural differences, in addition to a lack of transferable vocational skills and inadequate educational preparation, have contributed to many major acculturation problems such as high unemployment, poverty, a high rate of welfare participation, a significant generation gap, youth gangs, role change and conflict, mental health and medical problems. In the early 1980s many refugee workers concluded that the Hmong's adjustment to life in the United States was a "worst case situation".49 This statement reflects the difficulties that face both Hmong and American immigration, resettlement, and social service systems. While the United States is regarded as the land of immigrants, working with contemporary Asian immigrants and refugees such as the Hmong is new to this country. Previous immigrants to the United States were mostly from Europe. The European model or straight-line theory, which "includes voluntary immigration, acculturation, integration, assimilation, and eventual absorption into the dominany society" 50 is problematic for the Hmong. Unlike most prior immigrants the Hmong came to America as non-white refugees and brought with them their long history as an oppressed minority scarred by wars. Consequently they have a very different outlook and cultural experience. Nothing about America compares with anything from their past experience; adjusting to life here was beyond their coping skills and wisdom. Consequently the resettlement of the Hmong in the 1980s and early 1990s has been a challenging experience for both the Hmong people and for their adoptive land.

Fortunately the acculturation situation gradually improved toward the end of the 1990s. During the mid-1980s about half 


\section{Ethnic Studies Review Volume 24}

of the more than seventy Hmong American communities throughout the United States had already achieved self-sufficiency. ${ }^{51}$ By the end of the 1990s most Hmong American communities had adapted somewhat successfully to life in America and are fairly self-sufficient except for a few Hmong communities in Central California, especially Fresno, Visalia, Merced, Stockton, and Sacramento. The slow attainment of self-sufficiency for the Hmong in California's Central Valley might be partially due to the economy of this region which is based on agriculture and which does not offer the kinds of jobs the Hmong need to sufficiently provide for their families. 52 Many Hmong made their secondary migration to Central California with the hope of farming, but their hope turned sour when they realized that their slash-and-burn farming skills are not compatable with the highly mechanized agribusiness in Central California. Moreover they did not have the needed capital money or the technological and marketing skills needed to do agribusiness. As a result most of them were not able to support themselves from their small farming. A few of them continue to farm special crops, such as strawberry, Bok Choy, Lemon Grass, Bitter Melon, and so on. Although the Hmong in California's Central Valley have not yet achieved full self-sufficiency, they, too, have been able to reduce their welfare participation from about sixty percent in 1995 to just above twenty percent in 1999.53

\section{Gender Differences in Adaptation}

While many Hmong men adapt well to life in America, others do not. A study of Hmong men in 1993 reveals a diverse group with very different approaches to their adaptation to life in the United States. 54 The study classified them according to their outlook in life. The men fell into one of three groups: the past, present, and future-oriented.

- Past-oriented Hmong men emphasize the importance of their life in the past; they have a harder time adapting, and so they experience more acculturation problems.

- Present-oriented Hmong men focus on their daily life with no realistic goal(s) for the future.

- Future-oriented Hmong men focus their energies and thoughts on discussions and activities that will positively 
impact their future. They tend to have more education and access to resources and experience more social independence.

This study indicates that as members of the Hmong community have adapted to life in America differently, they have themselves become more diverse in the process. At one end of the continuum are those who do not adapt at all with tragic consequences. Hmong men have committed a few high-profile acts of self-directed violence, including a Hmong man in Sacramento who in the fall of 1999 killed his five children and himself. 55

The adaptation of Hmong women appears to be twosided. On the positive side many Hmong women tend to see America as the land of opportunity. They learn the language faster, having more interactions with their children, the teachers of their children, and other service providers. Hmong women can also earn an income sufficient to support their families and hold responsible jobs outside of the home. These factors might explain the substantial progress made by many Hmong women. The success stories of Hmong American women seem to be on the rise as we enter the 21st century. For instance a woman, Choua Lee, became the first Hmong to be elected to public office. Many Hmong women play important leadership roles in the Hmong American community, including chairing the first and second Hmong National Conferences. In California, three out of five Hmong lawyers are women. Hmong women have many strong associations, including the Association for the advancement of Hmong Women and the Hmong American Women's Association. The Executive Director of the Council of Asian Pacific Minessotans is a Hmong Woman. The two Hmong students attending Harvard University are women.

On the negative side many Hmong women live in America without attaining the full benefits of societal participation. Many of these women spend most of their time at home, with very little or no opportunity to get an education or to interact with American society. Many of them are home caring for their many young children, while others are home because of restrictions imposed upon them by their husbands or families. Consequently many of these women do not fully benefit from 
being in America, the supposed land of opportunity and freedom. Like Hmong men, many Hmong women continue to suffer from family, health, and/or mental problems. Violent cases involving Hmong women are known to occur. One of these cases is the case of a Hmong woman in St. Paul, Minnesota, who, in September, 1998, strangled her six children to death. 56

One of the many important factors that have influenced the progress and change for Hmong American women is educational opportunity. In the United States all children must attend school and are provided with free elementary and secondary education, regardless of gender. While Hmong girls tend to get less support from their parents, clan, and community to pursue higher education than Hmong boys, they are equally entitled under the law to get an education in America. As two decades have passed and they are more accustomed to life in America, Hmong American parents and community gradually are making more efforts to support both boys and girls to get higher education. This support is evident in many educational celebrations where both boy and girl are honored for their educational achievement. In 1999 the number of Hmong men and women students in many universities are almost equal. It appears that in California State University, Stanislaus, there are more Hmong women than Hmong men students, and this campusi Hmong Student Association is run by mostly Hmong women officers. This opportunity and accessibility to education, in addition to equal income earning power, is likely to continue empowering Hmong women to make more progress in the future, and this development is likely to move traditional Hmong sex roles toward the more egalitarian sex roles of mainstream America.

\section{Experiencing Discrimination}

The Hmong American community has suffered countless acts of discrimination; many began soon after their arrival. In 1984, thirty-two Hmong families in Fresno were illegally evicted from their apartments. The tenants fought back in a very American way. They took the case to court but the resulting out-of-court settlement of $\$ 278,000$ was well below the $\$ 34$ million judgment they originally sought. 57 On June 23, 1991, The Fresno Bee published an article describing the anger of many resi- 
dents of Tollhouse, a suburban community near the foothills of Fresno County, where Hmong burials and funeral practices had greatly distressed area residents. One resident, Tom Dean, was quoted as saying, "They [the Hmong] ought to go back to Hmong-land".58 A Hmong chapel burned down that month, and the cause remains a mystery. ${ }^{59}$ The likelihood that this represents an ethnic hate-crime remains.

In 1992 the Fresno City Council proposed an ordinance to make illegal the killing of animals without a permit. This was an indirect attack on Hmong religious practices, which involve animal killing. 60 In the mid-90s, many Hmong fruitstands along Shaw Avenue and other streets were burned down, some more than once. Touxia Xaochay Thao, a Hmong farmer in Fresno, stated that these fruitstands were torched at night so that no one would know who did it. He said some farmers had taken to bringing their valuable property home when they left at the end of the day. 61

In some cases media stereotypes and misleading details aggravate the problem of public perception of the Hmong. The Fresno Bee, in particular, has published headlines that played up ethnicity when the story is unfavorable. The article, "Hmong Girl Allowed To Go Home,"63 would be titled differently if she were not a Hmong. The title might then have been "Fresno Girl' or 'Clovis Girl' Allowed To Go Home." Another title, "Hmong Say GAIN Unfair" was misleading. The Fresno Bee reporter did not interview or survey the more than 30,000 Hmong in Fresno to come to that conclusion. In fact, the article said there were only $500 \mathrm{Hmong}$ who had participated in a demonstration to publicize their claim that GAIN was unfair. This kind of tainted journalism led a Cambodian refugee to observe, "When I do something wrong, it's because I'm Cambodian. When an American does something wrong, it's only because they're Mike or John."63 When referring to youth gangs, instead of identifying the gang by name, The Fresno Bee tends to identify them simply as Asian or Hmong gangs.

Hmong in other cities have also encountered many discriminatory acts. For example, the Hmong in Wausau, Wisconsin, were discriminated against when in 1993 a group of citizens successfully pushed to end the practice of busing their children to other schools, where they would be mixed with 
mostly Hmong students "to give all students..." in the words of a school official "...an equitable socioeconomic balance and learning environment." 64 While many good American citizens, groups, and organizations do their best to help the Hmong, many others do not welcome their presence and openly vent their hostility toward them.

\section{Hmong Americans at the Dawn of the new Millennium}

After twenty-five challenging years in America, Hmong Americans have already achieved much, yet have some serious challenges still ahead. Many of their most pressing difficulties stem from family problems, youth delinquency, health, and economic hardships. Often these problems result in tragedy. For example a Hmong man in Fresno was found guilty on September 29, 1999, of slaying his wife's lover.65 In February, 1999, a judge in Fresno sentenced a leader in gang rapes to eighty-six years.66 Hmong community leaders and elders were shocked at the news that three boys, ages ten, eleven, and thirteen, were arrested in September, 1999 for gang-raping an 8-year-old girl.67 And on October 11, 1999, Lee Pao Xiong, the President of Hmong National Development, announced that four Hmong girls from out of state were abducted at gunpoint and held for more than two weeks in Detroit. They were repeatedly raped by a dozen Hmong boys and young men in Detroit.68 This is just a sampling of the many problem areas that have arisen in the Hmong's attempt to acculturate to life in America at the dawn of this century.

On the other hand, Hmong Americans have had many successes and made many contributions to America, despite their short history in this country. Some of these successes are discussed below:

Education: Hmong did not have their own written system until 1953 and had not earned a doctorate until 1972. And although it was not until 1982 that the first Hmong earned an American doctorate, the Hmong make education one of their most important goals. By 1999 about 120 Hmong Americans-a third of them women-had completed their doctoral studies (including law, pharmacy, and other professional terminal degrees).69 Hmong women make up about three-fourths of all Hmong American lawyers, and in California, as mentioned earlier, 
three of the five Hmong lawyers are women. Although small in number Hmong American students are found in many American Ivy League institutions, including Harvard, Yale, and Stanford. A few Hmong also managed to be admitted to and/or complete their studies in American military academies, including West Point. A study in Minnesota found that Hmong students in St. Paul, Minnesota, in comparison with other students, have lower dropout rates, higher educational aspirations, and parents who place a high emphasis on education. ${ }^{70}$ If the picture portrayed by this study reflects the reality of the Hmong, many more Hmong youth are expected to excel in higher education over the next decade.

University Teaching: As of 2000 nine Hmong persons hold tenured and tenure-track university teaching positions, and many Hmong are in other non-tenure track teaching positions. Of these nine, four are tenured associate professors with five of them in California, two in Wisconsin, and one each in Minnesota and lowa.

Political Participation: With Choua Lee's election to the Board of Education of the St. Paul Public Schools in 1992, she became not only the first Hmong but the first former refugee from Indochina to be elected to public office. ${ }^{71}$ Choua Lee is a Hmong American political pioneer who set the precedent for a Hmong leadership tradition. Since her victory three Hmong persons have been elected to local school boards in Wisconsin and Minnesota, and three Hmong persons were elected to city councils (two in Wisconsin, and one in Omaha, Nebraska).

Business Enterprise: Since the Hmong first entered the United States in 1975 many have tried to engage in business enterprises. The early businesses of the Hmong were mostly of ethnic enclave businesses and economy involving grocery stores, automotive repair shops, car dealership, financial services, and insurance sales. Ethnic enclave businesses involve three main factors: an ethnic population and consumer market, low pay for work, and an apprenticeship relationship between owners and workers.72 In the 1990s, many Hmong have engaged in mainstream businesses such as professional services, health care, the high-tech industry, poultry farming, restaurants, and so on. For example the 10,000-Hmong community in Michigan has engaged heavily in restaurant busi- 


\section{Ethnic Studies Review Volume 24}

nesses; they own and operate more than 100 restaurants. The Hmong in North Carolina have invested in many sectors of poultry farming. Some Hmong in Wausau, Wisconsin do ginseng farming, and many Hmong in California engage in strawberry farming and other agriculture-related businesses. New York has a small number of Hmong, but a few invest in the high-tech and motel industries.

Self-help organizations: Hmong Americans have established many community-based organizations to serve their many communities throughout the country. For example the Resource Development Guide of Hmong National Development listed twenty-five Hmong organizations in California, six in Colorado, and ten in Minnesota. ${ }^{73}$ Among these organizations are Hmong National Development (national), Fresno Center for New Americans (local), Lao Family Community (local), Hmong American Women's Association (local), Association for the Advanced Hmong Women (local), Hmong American Partnership (local), and so on. Most Hmong associations serve both a social and economic function. ${ }^{74}$

Government Participation: Although small in number Hmong are now found working in many local, state, and federal government agencies. Most of them are civil servants, but a few are actively involved at local, state and federal government levels. For example Lee Pao Xiong of Concordia University Saint Paul has a long list of community and government involvement since his early twenties. Now in his early thirties he is the director of Government Relations of Concordia University Saint Paul and the immediate past president of Hmong National Development. He was the executive director of the Council of Asian-Pacific Minnesotans representing more than forty groups of Asian-Pacific Americans. He is on the Board of Directors of more than ten organizations, ranging from the local chamber of commerce to the powerful Metro Council. He is also one of the eleven Asian American community leaders invited to visit the White House and meet with President Bill Clinton in June, 1999.

\section{Hmong National Conference: The Hmong National} Conference is a yearly event for the Hmong, especially the educated and bilingual/bicultural Hmong Americans. It is organized by the Hmong National Development (a nationwide 
Hmong organization) to provide a forum for information exchange and dissemination, networking, discussion of contemporary issues, and, most importantly, empowering the youth to use their fullest potential in America. The first Hmong National Conference was held in St. Paul, Minnesota, in 1995. The second was in Sacramento, California; the third was in Eau Claire, Wisconsin, and the fourth conference was held in Denver, Colorado. The 5th National Conference, which was held in St. Paul, Minnesota from October 30 to November 2, 1999, became a historic conference for many Hmong youths. President Bill Clinton sent a video message recognizing Hmongs' challenges and contributions. It was the first time a sitting U.S. President addressed a Hmong conference. Participants of the 5th Conference included White House officials, members of Congress, and the mayor of St. Paul. About $1,000 \mathrm{Hmong}$ attended from all over the country and overseas.

\section{Hmong American Pathfinders}

Many Hmong individuals have risked going where no Hmong American has yet gone. Their stories are not only the success stories of the Hmong, but their pioneering spirits contribute to the educational, social, economic, and political progress of the Hmong. Here are a few of these Hmong American Pathfinders: Choua Lee: She was elected to the Board of Education of St. Paul Schools in 1992 when she was pregnant with her only child. She became the first Indochinese American to be elected to public office, despite being only twenty-two years old, female, and Hmong. She served one full term of four years. Currently she is an elementary teacher in St. Paul. She has a B.A. in elementary education from the University of Minnesota, and earned her Masters Degree in Education Administration in May, 1999.

Pa Foua Yang: She was probably the best known Hmong student in the 1980s and the only Hmong student ever to have been invited to the White House. She was an exceptional achiever in school, and as a result she was invited to the White House by then President Ronald Reagan. Pa Foua is also the first Hmong American woman physician and now practices medicine in Milwaukee, Wisconsin.

Joe Bee Xiong: He was elected to the Eau Claire City Council 
in 1996, the first Hmong person to be elected to a city council. He served a second term in 1998. He is also a Hmong traditional music player. He can play many Hmong traditional music instruments, including the Qeej, violin, and flute.

Xoua Thao: $\mathrm{He}$ is the first Hmong to graduate from Brown University with a medical degree and from Harvard with a Master of Public Health. He also earned a law degree (Juris Doctor) from William Mitchell College of Law in St. Paul. He has served as the president of the Hmong National Development, a nationwide Hmong organization established to assist the Hmong in America. He is the founder of Xoua Thao Medical Center and co-founder of Hmong Chamber of Commerce (St. Paul) and the Hmong Bar Association in Minnesota. He is also a student of Hmong culture, especially Hmong wedding rites and chants. He practices medicine and lives in the Twin Cities of St. Paul and Minneapolis.

Yee Chang Hang: $\mathrm{He}$ is the first Hmong person to graduate from West Point, the most prestigious military academy in the United States. Since his graduation in 1992, he has served in the army and currently holds the rank of captain.

Lee Pao Xiong: $\mathrm{He}$ is the director of Government Relations of Concordia University Saint Paul and a respected Hmong American community leader. He was among a group of Asian American leaders invited to meet with President Clinton in June 1999. In May, 2000, he was appointed by President Clinton to serve on the Commission on Asian Americans and Pacific Islanders and became one of only two Indochinese Americans to serve on this commission. The St. Paul Pioneers described Lee Pao Xiong as someone who might significantly contribute to the political development of St. Paul, including possibly being the mayor of that city. ${ }^{75}$

Vang Hang: This college dropout-turned-restaurant entrepreneur in Michigan has established eight restaurants in Michigan since the late 1980s. Mario's Labelle, his largest, has fifty employees, is open twenty-four hours, serves American, Chinese and Thai food, and has a gross annual sales of about $\$ 1.6$ million.

Teng Lee: Lee, who is a member of a small Hmong community in New York, is a chemist, an entrepreneur, and a Hmong community activist. He specializes in solid-state gas sensing 
technology, has a preference for the high-tech industry, and has devoted much effort to advocating Hmong causes and promoting the ideas of "Virtual Universal Hmong Nation" and Hmong are responsible for "Hmong." $\mathrm{He}$ is a strong supporter of Hmong youths-the people he calls the hopes, the dreams and the future of the Hmong people. Teng Lee joined the gas analysis instrumentation department of Leybold Inficon in the 1985. There he was exposed to the leading technology of the time in gas chromatography, mass spectrometry, Infrared/ Ultra-Violet (R/UV), Nuclear Magnetic Resonance (NMR), and other scientific methods in chemical detection and analysis. Since 1988 he has been assigned to do research and development works on solid-state gas sensing technology. He earned his first US patent in 1991 developing a ceramic sensor for the detection of halocarbon gases. He received the Product of the Year Award in 1993. He is now researching and developing the fourth generation of sensors: tiny sensing structures mounted on microchips. Through his fascination with science and technology, Teng holds an unflinching belief that science and technology must be used to bring a quantum leap in advancement to the Hmong people. He said, "They allow people such as Hmong to jump directly from pre-literacy to cuttingedge technology in a single generation," a process that would have taken centuries in the normal course of human development. Hence, their potential must be harnessed and exploited to quickly develop and empower the Hmong people." $\mathrm{He}$ is convinced that the proper applications of education, science/technology, and economics are the key to a survivable Hmong future, as he puts it, the savingr factor of the Hmong people. Consistent with this basic philosophy, he went on to co-found Illumination Technologies (IT) which specializes in developing state-of-the-art illumination systems for use in robotics and machine vision. He has founded other enterprises such as NCL, Inc., which engages in light assembly and Jayshau, Inc., which owns and operates motels. He is also involved in the software industry through Princeton Teaching Associates Software, Inc. which specializes in developing interactive multimedia educational software. His latest interest is in 100IG, Inc. which attempts to bring Hmong entrepreneurs to form a venture company with the intent to invest in and/or to 
acquire mainstream businesses.

Tou Ger Xiong. He is a college educated young Hmong artist, actor, comedian, family and youth consultant, rap musician, storyteller. He is well known among many Hmong youths. Tou Ger Xiong calls his performance Hmongrapcomedy, a combination of Hmong arts of storytelling, American rap music/performance, and comedy performance to tell the story of the $\mathrm{Hmong}$. He makes the old laugh and entertains the young with messages of life and wisdom. He makes the Hmong cry and opens non-Hmong eyes and hearts to the worldview and experience of the Hmong. His show and performance have inspired thousand of Hmong youth and their families throughout the country. Many of his performances focus on Hmong history on the Hmong experience of discrimination and acculturation in addition to the empowerment of Hmong youth to pursue education and realistic life goal. He also uses his performance to educate teachers and other service providers to better understand the Hmong and their experience. His arts and performance make him a well recognized Hmong person in the Hmong American community.

\section{Conclusion}

The Hmong bring with them to America a unique cultural and historical experience that has no exact parallel with any other prior ethnic immigrant group. They are not white, do not come from a Judeo-Christian background, and did not come to America as voluntary immigrants. Moreover they do not exactly resemble the earlier Asian immigrant groups to America either. They have a long history of being a minority within Asia and brought their minority status and experience with them ${ }^{76}$. Throughout their long history they have fought oppression and assimilation to survive as an ethnic group 77 . They tend to use multicultural approaches rather than pure assimilation to adapt to their American environment. Paul and Elaine Lewis concluded in their writing about the Hmong that "Hundreds of years of adversity have bred a spirit of independence; they [Hmong] value liberty and dignity above all easy living. The independence they seek, however, is not for the individual, but for the kin group, and the liberty they cherish is group liberty."78 Their age-old wisdom and spirit of independence have, in 
many ways, propelled the Hmong to survive their first two decades in America despite their many acculturation difficulties. The experience of the Hmong in America is a story of a people who have been through a trans-centennial change: from the rural mountain villages of Northern Laos to America, the most technologically developed country in the world. The Hmong, against all odds, have survived their first two very challenging decades in America. While the Hmong have achieved much in America, there are still many problems and barriers for them to overcome. This new millennium will be the real test for the Hmong in America. If they can manage to raise their very young population to do well in school, they will certainly become active participants in American social, economic, and political development. This task, however, is huge and might be beyond the wisdom of the Hmong to carry it out. To be able to raise their young successfully the Hmong may need to draw the best from their age-old parenting and coping skills and learn the best from other immigrants in America. There is a proverb that says, "After the rainy storm, the sun is bright and the sky clears."79 It is the hope of many Hmong that after all hardships and struggles the Hmong in America will have a life more fulfilling in peace, prosperity, strengths, equality, and democracy.

\section{Notes}

1 Kou Yang, The Experience of the Hmong in Fresno. A paper presented at the Western Conference of the Association of Asian Studies in Boise, Idaho, September 17-18, 1999.

2 To get a better Hmong perspective on their American experience, the author gathered information for the writing of this paper from key members of the Hmong American community, available literature, the 5th Hmong National Conference and the author's own observation and research. The latter came from his many roles and activities, including his summer 1999 tour of the Hmong in Minnesota, Wisconsin, Michigan, Nevada, Oregon, and California. He attended the 5th Hmong National Conference, which was held in November 1999, in Minneapolis, Minnesota. His observation is also from his role as a former social worker and as a current member of the faculty of Ethnic Studies at California State University, Stanislaus.

3 Yang Dao, Hmong: Enduring Traditions. Edited by Lewis, J. Rancho Cordova, CA: Southeast Asia Community Resource Center-Folsom 


\section{Ethnic Studies Review Volume 24}

Cordova Unified School District, 1992. 253.

${ }^{4}$ Robert Cooper, Nicholas Tapp, Gary Yia Lee, and Gretal SchwoerKohl. The Hmong. Bangkok, Thailand: Artasia Press, 1991. 8.

5 Yang Dao, Les Hmong du Laos face au Development. Vientiane, Laos: Siasavath Publishers, 1975.

6 Kay Yi Yang, Hmong-Mongolian? Hmong Forum, January 1996.

7 Nicholas Tapp, Sovereignty and Rebellion of the Hmong of Northern Thailand. Oxford: Oxford University Press, 1989.

8 Yang Dao, Hmong at the Turning Point. Edited by Blake, J. L. Minneapolis: WorldBridge Associates, 1993. XIV.

9 Jean Mottin, History of the Hmong. Bangkok: Odeon Book Store, 1980. 16.

10 Keith Quincy, Hmong: History of a People. Cheney, WA: Eastern Washington University Press, 1989.

11 Kay Yi Yang.

12 Kou Yang, The Multifaceted Intervention Model in Working with Hmong Families. MSW Thesis, California State University, Fresno.

13 Rhoad Murphey, A History of Asia (2nd Ed.). New York: HarperCollins, 1996.

14 Ronald Takaki, Strangers from a Different Shore. New York: Penguin Books, 1987.32.

15 Keith Quincy.

16 Jean Mottin, 47.

17 Kou Yang, The Hmong in Fresno: A Study of Welfare Participation and Self-Sufficiency. Ann Arbor, U.M.I Dissertation Services, 1995. 15.

18 Yang Dao, Hmong at the Turning Point. 36.

19 lbid. 38.

20 Roger Wagner, Backfire. 1995. New York: Simon \& Schuster, 1995.

21 Wilber Garrett, No Place to Run. National Geographic, 145(1), 78- 
111. 1974

22 Yang Dao, Hmong at the Turning Point.

23 Ibid.

24 lbid., 39.

25 Jean Mottin. 52.

26 Peter T. White, Laos. National Geographic, 176 (6), 1987. $772-$ 795.

27 Jacqui Chagnon and Roger Rumpf, Decades of Division for the Lao Hmong. Southeast Asia Chronicle, 91. 10-15.

28 Bruce T. Bliatout, Bruce T. Downing, Judy Lewis and Yang Dao, Handbook for Teaching Hmong -Speaking Students. Folsom Cordova, CA: Folsom Cordova Unified School District, Southeast Asia Community Resource Center, 1988. 10-15.

29 Jac Bulk, American Hmong on the move: Understanding Second. Ethnic Studies Review, 19, no1 (February 1996) . 7-28.

30 Roy Calkins \& D. A. Rios, Refugee Leader Fuels a Futile Dream. The Fresno Bee, 1989, July 23, A1.

31 Hmong Population in the US, Hmong National Development, available from $h$ ttp://members.aol.com/hndlink/popcount.htm

32 US Census Bureau, available from www.census.gov/apsd/wepeople.htm

33 Ibid.

34 Yang Dao, Hmong at the Turning Point. 22.

35 Kou Yang, The Hmong in Fresno: A Study of Welfare Participation and Self-Sufficiency. 26.

36 Kou Yang, The Hmong in Fresno: A Study of Welfare Participation and Self-Sufficiency.

37 Stevan Rosenlind, Welfare dependence drops among the Hmong in Fresno County. The Fresno Bee, 1 January 1995, sec. A14.

38 Kimberly Hayes Taylor, Better Jobs and Families Reunions Draw Thousands from Fresno to Twin Cities. The Fresno Bee, 27 October 


\section{Ethnic Studies Review Volume 24}

1998, sec. A1.

39 lbid.

40 US Census Bureau, available from www.census.gov/apsd/wepeople.htm

41 Wang Teng Yang, telephone interview by author, 16 January 1999.

42 Nancy D. Donnelly, Changing Life of Refugee Hmong Women. Seattle, WA: University of Washington Press, 1994. 19.

43 Ronald Takaki, Strangers from a Different Shore. New York: Penguin Books, 1989.33

44 lbid., 119.

45 Evelyn Nakano Glenn and Stacy G. H. Yap, Chinese American Families. Edited by Ronald L. Taylor. Upper Saddle River, New Jersey: Prentice Hall, 1998. 141.

46 Harry L. Kitano and Roger Daniels, Asian Americans: Emerging Minorities (2nd Ed.). Englewood Cliffs, New Jersey: Prentice Hall, 1998. 18.

47 Ibid.

48 Donald A. Ranard, The Hmong. In America 1, (January 1988).

49 Spencer Sherman, Resettling the Hmong. Reporter, 8(4). 1985. 18-22.

50 Harry L. Kitano and Roger Daniels, 2.

51 Donald A. Ranard, The Hmong. In America 1, (January 1988).

52 Kou Yang, The Hmong in Fresno: A Study of Welfare Participation and Self-Sufficiency.

53 Lue N. Yang, personal communication, 1999, September 10.

54 Kou Yang, Hmong Men's Adaptation to Life in the United States. Hmong Studies Journal, spring 1997. Available at WWW.como.stpaulk12.mn.us/Vue-Benson/HSJv1n2Yanghtml

55 Stephen Magagnini, Family Left to Wonder Why: Killings Derail a Hmong Mother's Search for Happiness. Sacramento Bee, 1999, December 10. 
56 Margaret Taus, Minnesota Mother, 24, in Custody in Strangling Death of 6 Children. The Fresno Bee, 1998, September 5.

57 Denice A. Rios, Discrimination Lawsuit Settled. The Fresno Bee, 1989, January 25. A1.

58 Alex Pulaski, Hmong Burials Wearing on Nerves in Tollhouse. The Fresno Bee, 1991, June 23. A1.

59 Louis Galvan, Hmong Chapel Fire Unresolved and May Never Be. The Fresno Bee, 1991, June 29. B1.

60 Jeremy Hein, From Vietnam, Laos, and Cambodia. Twayne Publishers, 1995. 110

61 Touxia Xaochay Thao, personal communication, 6 March 1999.

62 Alex Pulaski, Hmong Girl Allowed to Go Home. The Fresno Bee, 1994, October 10. A1.

63 Jeremy Hein, 143.

64 Richard T. Schaefer, Racial and Ethnic Groups, 8th Edition. Prentice Hall, 2000. 343.

65 Pablo Lopez, Husband Found Guilty in Slaying of Wife's Lover. The Fresno Bee, 1998, September 29. B3.

66 The Fresno Bee. Leader in Gang Rapes Sentenced to 86 Years. The Fresno Bee, 1999, February 19. B1.

67 Ashley Grant, Three Boys Arrested in Girl's Rape. The Associated Press, 1999, September 23.

68 The Associated Press, Four Teens Escaped Rapist Captors. The Associated Press, 1999, October 11.

69 Yang Dao, personal communication, 1999, July 23.

$70 \mathrm{McNall}$, Michael, T. Dunnigan, and J. T. Mortimer. The Educational Achievement of the St. Paul Hmong. Anthropology \& Education Quarterly, 25(1); 44-65, 1994.

71 Jeremy Hein, 105.

72 Min Zhou, Chinatown: The Socioeconomic Potential of an Urban Enclave, Temple University Press, 1992.

73 Hmong National Development, Resource Development Guide. 


\section{Ethnic Studies Review Volume 24}

Hmong National Development, 1995.

74 Jeremy Hein, 95.

75 Ronald Clark, "New Leader of Hmong Partnership Seeks More Cooperation, Less Rivalry." Saint Paul Pioneer Press, 7 Feb. 1993. A14.

76 Keith Quincy

77 Kou Yang, The Hmong in Fresno: A Study of Welfare Participation and Self-Sufficiency.

78 Paul Lewis and Elaine Lewis, People of Golden Triangle. New York: Thames and Hudson, 1984. 133.

79 Kou Yang, From Indochina to Fresno: A Brief Look at the Plight of the Indochinese in Fresno. Edited by Katsuyo Howard. Passage. Fresno, CA: California State University Press, 1990, xxv.

\section{Bibliography}

Bliatout, Bruce T., Bruce T. Downing, Judy Lewis, and Yang Dao. Handbook for Teaching Hmong-Speaking Students. Folsom Cordova, CA: Folsom Cordova Unified School District, Southeast Asia Community Resource Center, 1988.

Bulk, Jac, Hmong on the move: Understanding Secondary Migration. Ethnic Studies Review, 19(1). (February 1996). 7-28.

Cooper, Robert, Nicholas Tapp, Gary Yia Lee, and Gretel SchwoerKohl. The Hmong. Bangkok, Thailand: Artasia Press, 1991.

Chagnon, Jacqui and Roger Rumpf. Decades of Division for the Lao Hmong. Southeast Asia Chronicle, October 1983.

Donnelly, Nancy D. Changing Life of Refugee Hmong Women. Seattle, WA: University of Washington Press, 1995.

Garrett, W.E. No Place to Run. National Geographic 145, no.1 (1974): 78-111.

Glenn, Evelyn N. and Stacey Yap, Chinese American Families. 2nd Ed. Edited by Ronald L. Taylor. Upper Saddle River, New Jersey: Prentice Hall, 1998.

Grant, Ashley, Three Boys Arrested in Girl's Rape. The Associated Press, 1999, September 23. 
Hein, Jeremy, From Vietnam, Laos, and Cambodia. New York: Twayne Publishers, 1995.

Hmong National Development [cited 4 January 1999]. Available from http//members.aol.cpm./hndlink/popcount.htm

Kitano, Harry L. and Roger Daniels, Asian Americans: Emerging Minorities. 2nd Ed. Englewood Cliffs, New Jersey: Prentice Hall, 1998.

Lewis, Paul and Elaine Lewis, People of the Golden Triangle. New York: Thames and

Hudson, 1984.

McNall, Michael, Dunnigan, T. and J. T. Mortimer, J. T. (1994). The Educational Achievement of the St. Paul Hmong. Anthropology \& Education Quarterly 25, no.1 (1994): 44-65.

Mottin, Jean, History of the Hmong. Bangkok: Odeon Book Store, 1980.

Murphey, Rhoad, A History of Asia (2nd Ed.). New York: HarperCollins, 1996.

Quincy, Keith, Hmong: History of a People. Cheney, WA: Eastern Washington University, 1988.

Ranard, Donald A. The Hmong. In America, 1. (988).

Schaefer, Richard T. (2000), Racial and Ethnic Groups. Upper Saddle River, New Jersey: Prentice Hall.

Sherman, Spencer, (1985), Resettling the Hmong. Reporter 8, no. 4 (1985): 18-22

Takaki, Ronald, Strangers from a Different Shore. New York: Penguin Books, 1989.

Tapp, Nicholas, Sovereignty and Rebellion of the Hmong of Northern Thailand. Oxford: Oxford University Press, 1989.

U.S. Census Bureau (1990). We the Americans: Asians [cited 4 January 1999]. Available from: www.census.gov.apsd/wepeople.htm

White, Peter T. Laos. National Geographic 176, no. 6 (1987): $772-$ 795. 


\section{Ethnic Studies Review Volume 24}

Yang, D. \& North, D. (1988, November). Profile of the Highland Lao Communities in the United States. Washington, D.C.: The U.S. Department of Health and Human Services, Family Support Administration, Office of Refugee Resettlement. Contract \# DHHS/PHS 282-87-1012.

Yang Dao. Les Hmong du Laos Face au Development. Vientiane, Laos: Siasavath Publishers, 1975.

The Hmong: Enduring Traditions. Edited by Judy Lewis. Rancho Cordova, CA: Southeast Asia Community Resource CenterFolsom Cordova Unified School District, 1992.

Minneapolis:

Hmong at the Turning Point. Edited by Jean L. Blake. WorldBridge Associates, 1993.

Yang, Kou, From Indochina to Fresno: A Brief Look at the Plight of the Indochinese in Fresno. Edited by Katsuyo Howard. Fresno, CA: California State University, 1990.

The Multifaceted Intervention Model in Working with Hmong $\bar{F}$ amilies. MSW Thesis. California State University, Fresno, 1991.

The Hmong in Fresno: A Study of Welfare Participation and Self-Sufficiency. Ann Arbor, U.M.I. Dissertation Services, 1995.

Zhou, Min, Chinatown: The Socioeconomic Potential of an Urban Enclave. Philadelphia: Temple University Press, 1992. 